\title{
Reproduksi Paham Keagamaan dan Respon Terhadap Tuduhan Radikal (Studi Kasus Pesantren Ngruki Pasca Bom Bali 2002)
}

\author{
Muhamad Murtadlo \\ Puslitbang Pendidikan Agama dan Keagamaan, Balitbang dan Diklat Kemenag RI \\ tadho25@gmail.com \\ Artikel diterima 19 April, diseleksi 7 Juli, dan disetujui 28 Juli 2017
}

\begin{abstract}
Pesantren Al Mukmin Ngruki Sukoharjo is often cited as an inspiration for radical Islam in Indonesia. This research examines the reproduction of religious understanding and the response to allegations of radicalism addressed to Pesantren Ngruki after the Bali bombings of 2002. This study includes qualitative research with case study approach. This study argues that a radical view of Islam can not be separated from social and historical context of this Islamic boarding institutions. Currently Pesantren Ngruki has undergone some changes in the orientation of education resulting from multiple causes, which are not limited by the case of Bali bombings only.
\end{abstract}

Keywords: Pesantren Al Mukmin Ngruki, Salafi, Radicalism.

\section{Pendahuluan}

Pasca peristiwa Bom Bali 2002, Pesantren Al Mukmin Ngruki Sukoharjo Jawa Tengah (selanjutnya disingkat Pesantren Ngruki)menjadi sorotan baik media nasional, maupunmedia internasional. Pesantren Ngruki dicurigai mengajarkan paham agama yang membolehkan santrinya melakukan tindakan teror. Tuduhan itu diakui atau tidak cukup merepotkan penyelenggara pendidikan pesantren tersebut. Pesantren Ngruki dicitrakan sebagai pesantren radikal dihubungkan dengan sikap para pendiri pesantren tersebut, khususnya Abdullah Sungkar dan Abu Bakar Baasyir

\begin{abstract}
Abstrak
Pesantren Ngruki Sukoharjo sering disebutsebut sebagai inspirasi Islam radikal di Indonesia.Penelitian ini ingin mengkaji reproduksi paham keagamaan dan respon atas tuduhan Islam radikal yang dialamatkan pada pesantren Ngruki, pascaperistiwa Bom Bali 2002.Penelitian ini termasuk penelitian kualitatif denganpendekatan studi kasus.Penelitian ini menyimpulkan bahwa pandangan Islam radikal tidak bisa dilepaskan dari konteks sosial dan historis dari lembaga pesantren ini. Saat ini pesantren Ngruki telah mengalami beberapa perubahan dalam orientasi pendidikan yang dihasilkan dari beberapa sebab, yang tidaksemata-mata karena dampak bom Bali.
\end{abstract}

Kata-kata kunci: Pesantren Ngruki, Salafi, Radikalisme.

yang sering dianggap berseberangan dengan negara seperti ketidakmauan mengikuti upacara bendera, tidak mau menghormat bendera dan penolakan terhadap peng-asas tunggal-an Pancasila.

Pengkaitan kata "teror" terhadapkeberadaan pesantren Ngruki membawa konsekwensi tersendiri bagi pesantren tersebut. Menurut salah satu alumni Pesantren ini, pemberitaan negatif terhadap pesantren telah menyebabkanpenurunan jumlah santri pada suatu waktu. Penurunan jumlah santri paling dirasakan terjadiantara 2003 hingga 2005, setahun setelah peristiwa bom Bali. 
Beberapa upaya dilakukan untuk untuk memulihkan nama pesantren baik dilakukan pihak pengasuh maupun oleh alumni. Pada tahun 2006, Pesantren Ngruki mencoba menggelar reuni akbar dengan mengundang Presiden RI waktu itu, Susilo Bambang Yudhoyono. Namun, karena pertimbangan sesuatu hal, presiden hanyamengutus menterinya untuk datang (Okezone.com, 18/9/2012). Setelah peristiwa Bom Bali, Pesantren Ngruki harus berjuang untuk mempertahankan lembaga pendidikannya di tengahtengah berbagai tuduhan dan fitnahan. Beberapa perubahan terjadi di pesantren ini sebagai ikhtiar pesantren ini dalam menyelenggarakan tafaquh fiddin.

Stigma garis keras semakin diarahkan ke pesantren ini. pengkaitan Pesantren Ngruki dengan terorisme tidak lepas dari upaya perlawanan para pendiri pesantren terhadap pemerintah, seperti ditunjukkan Abdullah Sungkar.Abdullah Sungkar dikenal vokal menentang pemberlakuan Pancasila sebagai dasar negara yang untuk mengatur kehidupan bermasyarakat di Indonesia. Saat itu, Indonesia dipimpin presiden Soeharto. Sejak itu, aktivitas Pesantren Ngruki selalu dipantau. Terlebih, saat pesantrenini kedatangan tokoh Negara Islam Indonesia (NII), Kartosuwiryo. Padahal para pendiri dan pengelola pesantren ini tidak sepenuhnya sejalan dengan ide NII. Bahkan konon Baasyir dan Abdullah Sungkar pernah berbeda pendapat. Keduanya pernah sempat bersitegang. Tidak hanya itu, Baasyir menolak masuk ke Jamaah Islamiyah (JI) yang didirikan Abdullah Sungkar.

$\begin{array}{ccr}\text { Melihat } & \text { fenomena } \begin{array}{r}\text { yang } \\ \text { memposisikan }\end{array}\end{array}$ sebagai pusat Islam garis keras dan danyak dikaitkan dengan peristiwa bom di berbagai tempat di Indonesia, penelitian inimerumuskan pertanyaan untuk dijawab: Bagaimana reproduksi paham keagamaan dan radikalisme pada
Pesantren Ngruki setelah peristiwa Bom Bali 2002. Apakah di dalam pesantren terjadi beberapa perubahan kebijakan pendidikan? bagaimana pula respon Pesantren Ngruki terhadap tuduhan radikalisme pada pesantren ini.

Untuk menjawab rumusan permasalahan, penelitian menggunakan pendekatan kualitatif dengan model studi kasus.Kasus sudah dipilih sejak awal, yaitu Pesantren Ngruki pasca Bom Bali 2002 yang dikaitkan dengan bagaimana pesantren ini mengembangkan paham keagamaan dan merespon tuduhan radikalisme. Pengumpulan data dilakukan dengan cara pengamatan, wawancara dan studi dokumen. Pengamatan dilakukan dengan datang langsung ke lokasi. Wawancara dilakukan dengan pimpinan pesantren, ustad dan para alumni. Studi dokumen dilakukan dengan melihat kurikulum pendidikan serta penelusuran hasil-hasil penelitian dan reportase terhadap pesantren ini.

Di dalam memahami permasalahan, peneliti mencoba menganalisis dengan melalui pendekatan sosiologis dan historis. Analisis sosiologis digunakan untuk memahami konteks sosial pesantren Ngruki di Surakarta; sedangkan analisis historis digunakan dalam membaca dinamika pesantren ini dari awal pendirian, peran tokoh-tokoh yang ada di dalamnya dan perkembangan yang terjadi dalam sistem pendidikan setelah pesantren ini dikaitkan dengan peristiwa Bom Bali 2002. Selanjutnya data dipaparkan dengan teknik deskriptif analisis.

Secara konseptual, reproduksi paham keagamaan atau ideologi, menurut Althusser terjadi dalam tiga bentuk, yaitu: 1) perubahan paham melalui apa yang disebutnya sebagai Repressive State Aparatus (RSA). Perubahan ideologi yang disebabkan paksaan dari negara; 2) perubahan paham ideologi yang disebutkan sebagai Ideological State 
Aparatus (ISA), yaitu perubahan yang lebih halus melalui media, pendidikan, keluarga, agama; 3) perubahan melalui interpelasi (keterpanggilan), yaitu paham yang berubah secara alami sesuai struktur yang menjadi konteks yang berubah-rubah dari pada subyek. Tanpa sadar individu sudah menjadi penopang sebuah ideologi tertentu dalam menjalani proses hidupnya (Althusser, 2008: xvi). Model-model reproduksi paham keagamaan seperti ini akan kita jadikan patokandalam melihat fenomena perubahan paham keagamaan di pesantren Ngruki Sukoharjo.

Berbagai tulisan pernah mencoba mengkaji pesantren Ngruki setelah Bom Bali. Diantaranya Fuaduddin dkkyang menulis Pondok Pesantren Islam Al Mukmin Ngruki Solo (Puslitbang Pendidikan Agama dan Keagamaan, 2004). Tulisan ini panjang lebar mencoba mendeskripsikan pesantren Ngruki dengan segala kegiatan dan jaringan yang dimiliki Pesantren Ngruki. Buku ini cukup lengkap, walaupun banyak bagian yang diungkap yang tidak terkait dengan Ngruki. Namun secara umum dapat mengenalkan pesantren Ngruki.

Yuli Nurhasanah(2013) dalam tulisannya berjudul "Pondok Ngruki dan Issu Terorisme dalam Pergumulan Wacana Public" menyatakan bahwa ternyata kebanyakan orang tua santri mengirimkan anaknya ke pesantren ini karena kualitas pendidikannya. Mereka tidak menghiraukan segala label negatif yang ditimpakan oleh media bahwa pesantren ini radikal, atau banyak alumninya yang terlibat tindakan terorisme. Dari sisi kualitas, Pesantren Ngruki dipercaya masih melakukan pembelajaran agama yang lebih puritan dibandingkan pesantren atau lembaga pendidikan Islam yang lain.

Penelitian lain yang terkait dengan pesantren Ngruki, khususnya salah satu pendiri utama Pesantren Ngruki yaitu Abdullah Sungkar. Mutoharun Jinan
(2014: 409) yang meneliti tiga tokoh yang dominan mewarnai Solo, yaitu Abdullah Sungkar (Pendiri Pesantren Ngruki), Abdullah Marzuki (Pendiri Pesantren Assalam) dan Abdullah Thufail (Pendiri Majlis Tafsir Al-Qur'an/MTA) menyimpulkanbahwalatarbelakangyang berbeda antara satu tokoh dengan tokoh lain, meskipun hidup dalam konteks dan zaman yang sama, membuahkan pola perjuangan dan strategi gerakan yang berbeda.

\section{Surakarta: Membaca Konteks}

Sebagai sesama pecahan dari kerajaan Islam Mataram, pengkaji menduga kedua kraton ini mempunyai kemiripan, di mana kraton memainkan simpulsosialbudayadidaerahnya.Namun ternyata setelah mengkaji fenomena pergerakan agama dan ideologi, ternyata asumsi pengkaji itu berbalikhampir 180 derajat. Pengkaji sebagai orang yang dilahirkan di Yogyakarta, tadinya mengira tidak akansusah memahami relasi sosial masyarakat kota Surakarta, karena kedua kota mempunyai akar historis yang sama. Di kota Yogyakarta pengkaji memahami kraton mampu memerankan secara maksimal sebagai simpul kota budaya, sehingga semua kelompok sosial dan ideologi dapat hidup berdampingan secara harmonis. Sementara di Surakarta, pengkaji mendapati kota yang penuh pergumulan kelompok atau paham, bahkan ideologis, yang satu sama lain saling mengintip dan berkontestasi secara vulgar bahkan tidak menutup kemungkinan mudah terbakar menjadi kerusuhan sosial. Berkali-kali peristiwa kerusuhan sosial terjadi di kota Surakarta seperti peristiwa 1998 banyak ruko dan tempat perbelanjaan dibakar oleh massa.

Islam di kota Solo saat ini telah mempunyai sejarah yang panjang, yaitu semenjak pusat kekuasaan Mataram dipindahkan dari Pleret (Bantul) ke 
Kartosuro (1680) oleh Amangkurat II. Perpindahan itu disebabkankarena kraton Mataram lamapernah diduduki oleh pemberontak, maka bagi penguasa saat itu dipandang lebih baik pindah ke tempat baru. Maka dipilihkan pusat kerajaan Mataram di Kartosuro. Namun ternyata di tempat baru, istana Mataram juga pernah diduduki pemberontakan (geger Pecinan), maka pada tahun 1745, kraton pindah lagi ke Solo. Maka kota baru ini dinamai mirip dengan istana lama, di mana sebelumnya bernama Kartosura, di kota baru dinamai dengan penyebutan terbalik menjadi Surakarta (Kartosuro menjadi Surokarto). Sejak saat itu wilayah Surakarta menjadi pusat kekuasaan dan sekaligus menjadi pusat pergerakan baik pemikiran maupun ideology di Jawa. Surakarta menjadi arena kontestasi berbagai gerakan social seperti kekuatan kolonialisme (VOC) versus kepentingan politik pribumi, Tionghoa Vs Pribumi, gerakan Islam kejawen dengan Islam puritan, termasuk ideology komunisme dan kontestasi muslim dan non muslim terjadi di kota itu.

Untukmemajukan pendidikan Islam, pada akhir abad ke-18 Susuhunan membangun lembaga pendidikan IslamPesantren Jamsaren. Di pondok ini Kiyai Zamahsari (Jawa: Jamsari) mengajar kitab-kitab agama kepada para santri yang datang tidak saja dari sekitar Surakarta, tetapi juga dari daerah lain di Jawa. Para pangeran pada umumnya menempuh pendidikan agama di tempat yang lebih terkemuka, Pondok Tegal Sari di Ponorogo, sebuah pesantren besar yang dipimpin oleh Kiyai Kasan Besari yang sangat 'alim, tempat dahulu Susuhunan Paku Buwono II menyepi dan mendapatkan ketenangan batin tatkala terusir dari kratonnya oleh pembrontakan Cina. Di luar kraton, Belanda mendirikan sekolah Europesch Lager School (ELS) untuk mendidik anak-anak mereka, tetapi anak-anak ningrat juga dibolehkan memasuki sekolah ini. Untuk orang pribumi Belanda mendirikan Sekolah Gubernemen. Kraton sendiri juga mempunyai lembaga pendidikan yang bernama Sekolah Kesatrian.

Tercatat di Surakarta berdiri madrasah pertama di Indonesia, yaitu madrasah Mambaul Ulum (tahun 1905) oleh sejumlah ulama terkemuka Surakarta di bawah pimpinan Mas Pengulu Tapsiranom. Madrasah ini merupakan lembagapendidikan Islam yang mengadopsi cara Barat, baik dalam metode maupun sistemnya, tetapi isi kurikulum dikembangkan sendiri. Sekolah ini selain mengajarkan agama dan bahasa Arab juga pelajaran umum, seperti menulis Latin, berhitung, bahasa Belanda dan ilmu bumi. Mambaul Ulum sangat terkenal pada masa sebelum perang, dan di jaman kemerdekaan walaupun zaman telah berubah tetapi nama Mambaul Ulum tetap lestari sampai sekarang: Sekolah Tinggi Agama Islam dan Sekolah Tinggi Keperawatan Mambaul Ulum (Muhammad Hisyam, 2012).

Bibit awal gerakan yang mementingkan "Islam" yang awalnya bernuansa politik, dimulai tahun 1927yaitu ketika semakin menguatnya polarisasi Islam ke kelompok modernis (muhammadiyah) dan tradisionalis (nahdlatul Ulama). Untuk menjaga umat dalam posisi tengahnya, maka ulama Solo berkumpul menentukan sikap untuk tidak larut dalam polarisasi tersebut, mendirikanorganisasi Al-Islam, sebuah organisasi masyarakat yang bergerak di bidang pendidikan dan dakwah. AlIslam lahir karena adanya keprihatinan sejumlah ulama terhadap perkembangnya bermacam-macam orientasi keagamaan di Surakarta. K.H. Imam Ghozali yang memimpin organisasi ini mencoba menyatukan berbagai firqah keagaman untuk mengajak kembali kepada Qur'an dan Hadits. Semangatnya untuk menyatukan Islam, dan mengembangkan orientasi yang independent terhadap dua 
organisasi mainstream Muhammadiyah dan NU, mendorong Imam Ghozali merangkul semua kalangan ulama untuk mengembangkan pendidikan Islam yang imparsial (Stensilan, 1978)

Sedikit kiprah KH Imam Ghozali, berlanjut dengan pendirian Pesantren Luhur (1940), semacam universitasnya pesantren untuk menampung pemuda tamatan Sekolah Al Islam dan Mambaul Ulum yang ingin melanjutkan studi lebih tinggi yang digagasdengan $\mathrm{KH}$. M. Adnan (Pengulu Landraad), H.M. Rasyidi, BA.Di tahun 1948, Persatuan Guru Madrasah Republik Indonesia (PGMRI) bekerjasama dengan Al-Islam menyelenggarakan Kongres Pendidikan Islam yang diikuti oleh antara lain: Prof. Kahar Muzakir (Muhammadiyah), K.H. Wahid Hasyim (NU), KH. Imam Ghozali (Al-Islam), KH. Abdul Hamid (Pesantren Tremas), KH. Imam Zarkasyi (Pesantren Gontor), KH. Imam Mursyid (Pesantren takeran) dan lain-lain. Kongres yang diikuti oleh organisasi-organisasi Islam yang mempunyai lembaga pendidikan ini membicarakan cara mengembangkan pendidikan Islam di alam kemerdekaan.

Gagasan puritanisme Islam berkembang di Solo setelah tahun 19601970-an. Mutoharun Jinan menyebutkan bahwa pada tahun 1960-an di Surakarta berdiri tiga gerakan Islampuritan yang pengaruhnya sangat besar dalam dinamika Islam saat ini, Majelis Tafsir Al-Quran (MTA), gerakan Jamaah AlIslamiyah, yang salah satu tokohnya nantinya turut merintis Pesantren Ngruki, menekankan perjuangan penegakan syariah Islam melalui kekuasaan, dan Majelis Pengajian Islam (MPI) yang menggabungkan antara usaha penerbitan dengan pendidikan IslamMutoharun Jinan (2014: 409).Di sadari bahwa oleh kondisi umat Islam yang telah berjuang sejak zaman Belanda untuk melakukan emansipasi, baik secara politik, ekonomi, maupun kultural, justru nasibnya semakin lama semakin terpinggirkan. Salah satu alasan pendirian gerakan puritanisme yang dilakukan Majlis Tafsir Al-Qur'an, seperti disampaikan pendirinya, Ustadz Abdullah Thufail Saputra percaya bahwa kondisi tidak menyenangkan yang meliputi Muslim Indonesia disebabkan mereka tidak memahami Al-Qur'an. Menurutnya, Islam hanya akan emansipasi jika mereka kembali ke Al-Qur'an. Ustadz Abdullah Thufail Saputra yakin bahwa umat Islam Indonesia hanya akan dapat melakukan emansipasi apabila umat Islam mau kembali ke Al-Qur'an (Ahmad Asroni, 2012).

Pesantren Ngruki yang didirikan oleh salah satunya Abdullah Sunkar di anggap sebagai salah bentuk reproduksi dari salah satu pilar utama gerakan puritanisme di Sukoharjo. Pendidikan ini berawal dari pendirian Madrasah Diniyah di jalan Gading Kidul 72 A Solo.Pesantren Ngruki ini berdiri 1972. Kegiatan di Gading ini digagas oleh tokoh-tokoh seperti Abdullah Sungkar, Abu Bakar Baasyir, Abdul Qahar dan Yoyo Rosywandi. Karena para tokohnya secara politik sering berbeda dengan pemahaman mainstream umat Islam, maka pesantren ini sering dituduh menyebarkan pahama Islam radikal, atau lebih jauh lagi "Islam teroris." Tentu sebutan ini menyesakkan hati tidak saja bagi Pesantren Ngruki, tetapi juga pada dunia pesantren pada umumnya.

Pada tahun 1999, Abdullah Sungkar kembali ke Indonesia. Tidak lama kemudian dia meningal. Sebelum meninggal sempat terdengar kabar bahwa dia belum mau menerima seruan Usama bin Laden. Namun hingga beliau wafat, abdullah Sungkar belum merespon seruan Usama yang dibawa oleh Hambali. Sepeninggal Abdullah Sungkar, Hambali namunpaknya bergerilya secara liar untuk merekrut kader. Maka kalau kita saksikan seblum 1999, di Solo belum terdengar 
paham istishad (usaha menjadi syuhada). Maka meninggalnya Abdullah Sungkar seakan menjadi babak baru puritanisme di Solo yang memberi pemahaman baru bahwa istishad merupakan salah satu bentuk jihad.

\section{Sejarah dan Transformasi Pesantren Ngruki}

Pesantren Ngruki Sukoharjo, setelah peristiwa bom Bali 2002, telah mengalami beberapa pergeseran warna pendidikan pesantren tersebut. Sebetulnya beberapa pergeseran yang terjadi di Pesantren Ngruki tidak disebabkan secara langsung oleh adanya bom Bali 2002. Jauh sebelum bom Bali, sebenarnya pergeseran Pesantren Ngruki ke arah lembaga pendidikan yang lebih modern dan akomodatif telah berlangsung. Bom Bali yang salah satu pelakunya dikaitkan dengan alumni Pesantren Ngruki menjadi warna tersendiri di tengah upaya para pengelola yang ingin menjadikan lembaga pendidikan Pesantren Ngruki menjadi lembaga pendidikan yang lebih modern.

Pesantren ini berlokasi di NgrukiCemaniGrogol Sukoharjo. Cikal bakal Pesantren Ngruki berasal dari perbincangan beberapa tokoh Islam di Masjid Besar Surakarta. Dari perbincangan itu lahirlah ide mendirikan madrasah diniyah di Gading. Kegiatan dakwah di Gading ini berkembang pesat bahkan sempat mempunyai pemancar radio. Karena peminatnya semakin besar, maka proses belajar mengajar dipindahkan ke Ngruki, Cemani, Grogol Sukoharjo. Secara kebetulan ada tanah wakaf seluas 4 hektar. Maka pada tahun 1974, resmilah lembaga pendidikan Al Mukmin di dusun ini yaitu Ngruki, sehingga sampai sekarang terkenal dengan pesantren Ngruki.

Di wilayah Desa Cemani ini terdapat kompleks pesantrenNgruki.
Kompleks ini terdiri dari empat gedung berlantai tiga. Dua gedung adalah asrama, masing-masing berisi sekitar 40 ruangan yang digunakan untuk kamar tidur santri. Masing-masing ruangan mampu menampung sekitar 25 santri. Gedung santri laki-laki dan santri perempuan dipisahkan. Dua gedung lainnya untuk kegiatan belajar mengajar setingkat Madrasah Tsanawiyah dan Madrasah Aliyah.

Pesantren Ngruki dalam buku profilnya dalam penyelenggaraan pendidikan mempunyai misi ingin mewujudkan dua hal yaitu: 1) terbentuknya generasi Muslim yang siap menerima dan mengamalkan Islam secara kaffah (menyeluruh dalam segala aspek kehidupan; dan 2) mempersiapkan kehadiran ulama.

Untuk mewujudkan cita-cita itu, maka konsep Islam yang kaffah itu diterjemahkan (Publikasi Humas PPIN, 2014:20-21)dalam bentuk lahirnya generasi muslim dengan karakteristik : Salimul aqidah (generasi bertauhid murni yang mewarnai seluruh kehidupan); Sohihul Ibadah (beribadah dengan benar yaitu ikhlas lillahi ta'ala dan mengikuti contoh rosulullah), Matinul Khuluq (berakhlak mulia sebagaimana dicontohkan rosulullah), mutsaqoful fikri (berwawasan/ berilmu pengetahuan yang luas), Qowiyul jismi (jasmani yang kuat dan sehat), Qodiran alal Kasbi (mempu hidup dengan mandiri, tidak menjadi beban orang lain), Nafi'an linafsi walighoirih (bermanfaat bagi diri dan orang lain), Mujahidan lidiinihi (mengerahkan sseluruh potensinya untuk agamanya)

Pesantren Ngruki dalam mewujudkan cita-cita lembaga telah mengalami pasang surut. Secara garis besar, perkembangan Pesantren Ngruki dipengaruhi oleh dua kecenderungan: pertama, keinginan sebagian pengelola agarpesantreninimenjadipesantrensalafi; kedua, keinginan sebagian yang lain agar 
pesantren Ngruki ini menjadi pesantren modern. Keinginan agar Pesantren Ngruki mengembangkanpaham salafi berawal dari keinginan para pendiri pesantren ini sejak rintisan madrasah diniyah di Gading Kidul 72 A (Abdullah Sungkar dkk.) Sedangkan gagasan mengembangkan pendidikan modern kalau ditelusuri berasal dari lembaga pendidikan yang pernah ada sebelum 1972, yaitu lembaga pendidikan Al Amin yang dipimpin Muhammad Amir, $\mathrm{SH}$.

Dinamika pencarian bentuk yang paling ideal diantara dua kubu itu mewarnai sepanjang sejarah pesantren ini. Dari tahun pendirian hingga saat terakhir penulis mengkaji, Pesantren Ngruki telah mengalami beberapa masa penting. Sebagai kompromi antara dua corak ini, maka dalam bacaan penulis Pesantren Ngruki menjadi pesantren Salafi yang modern, atau pesantren modern yang salafi.Masa pra pesantren al mukmin, pendirian Al mukmin di Gading (1972), pemimpin Pesantren terkena kasus politik (1979), Pesantren ditinggalkan pendirinya mengungsi ke Malaysia (1984), terjadinya eksodus besar-besaran ustadz dan santri Nguki (1995), terjadi peristiwa Bom Bali yang dikaitkan dengan Pesantren Ngruki (2002), masa integrasi dan perubahan managemen (2006-2016).

Sebelum Pesantren Ngruki berdiri, menurut penuturan salah satu pengurus Yayasan (Muhammad AmirSH) sudah ada lembaga pendidikan Islam bernama Al Amin yang mempunyai santri 12 orang mahasiswa. Lembaga ini menempati tanah wakaf seluas $600 \mathrm{~m} 2$. Pusat kegiatan lembaga pendidikan ini berada di masjid At Taqwa. Pada tahun 1965, ada orang yang memberikan wakaf, seluas $7000 \mathrm{~m} 2$ yaitu $\mathrm{KH}$ Abu Amar yang berasal dari Jamsaren kepada lembaga pendidikan ini. Tanah inilah yang nantinya digunakan untuk mengembangkan pesantren yang dimotori oleh Abdullah Sungkar, Abu Baasyir dan beberapa teman lainnya)
Pada tahun 1972,Abdullah Sungkar dan kawan-kawan menggagas lembaga pendidikan di Gading No.72 A. Lembaga pendidikan ini mendapatkan sambutan dari masyarakat. Tidak lama kemudian, lembaga pendidikan ini juga berdakwah melalui siaran radio, yaitu RADIS ( Radio Dakwah Islam). Karena peminat yang meningkat dan membutuhkan tempat yang lebih memadai, maka ditawarilah Abdullah Sungkar dkkuntuk mengembangkan pesantren dengan menempati tanah wakaf dari $\mathrm{KH}$ Abu Amar. Maka terjadilah penggabungan pengurus pendidikan ini antara para pengelola lembaga pendidikan Al Amin dengan Al Mukmin. Maka meleburlah pesantren dengan jumlah santri yang lebih kecil ke Yayasan Al Mukmin yang semakin ke belakang semakin banyak santrinya.

Tahun 1984, beberapa pendiri Pesantren Ngruki yaitu Abdullah Sungkar dan Abu Bakar Baasyir meninggalkan Indonesia karena ada kecenderungan dari pengadilan bahwa vonis masa tahanan merekaterkait tuduhan subversi karena menentang asas tunggal Pancasila akandiperpanjang. Sepeninggal para pendiri, pengelola Pesantren Ngruki memahami masa itu sebagai masa peneguhan pendidikan pesantren di Ngruki. Antara tahun 1984-1995, Fuaduddin dkk (2004:)menyebut sebagai masa survival bagi pesantren Ngruki. Pada saat itu, perlunya memperbaharui sistem pendidikan Pesantren Ngruki mulai dirasakan.

Pada tahun 1995, kecenderungan pembaharui sistem pendidikan Pesantren Ngruki semakin menguat.Terjadilah sebuah sikap protes besar-besaran dari santri pesantren Ngruki dan menandai era baru Pesantren Ngruki.Pemantik terjadinya protes itu adalah dimulai usaha pendirian Madrasah Mutawasithoh (MMT)oleh kubu modernis pada tahun 1995. Rintisan program MMT ini 
nanti terkesan yang seakan menggeser keberadaan lembaga yang sudah establish sebelumnya, yaitu pendidikan muallimin. Sebagai protes para pengajar Madrasah Muallimin banyak melakukan penolakan, dan ujungnya terjadi eksodus guru dan santri (keluar dari pondok) besarbesaran. Maka terjadilah aksi keluar dari pondok beberapa guru dan santri yang jumlahnyamencapai hingga ratusan santri.

Pada tahun 2002, pesantren Ngruki mendapat musibah karena intitusi ini dikaitkan dengan peristiwa Bom Bali 2002. Alumni Pesantren Ngruki disebut-sebut terlibat dalam peristiwa pengeboman tersebut. Pesantren Ngruki menjadi sorotan, tidak saja dalam media nasional, tetapi juga di media internasional. Akibat opini tersebut, muncul kesan seakan-akan Pesantren Ngruki menyelenggarakan pendidikan untuk menghasilkan teroris. Kesan ini ditambahi dengan keterkaitan alumni Ngruki yang lain dalam peristiwa yang lain seperti peledakan Mariot.

Beberapa nama penting yang pernah memegang peran strategis dan sekaligus mewarnai sejarah Pesantren Ngruki dapat disebutkan antara lain seperti Abdullah Sungkar, Abu Bakar Ba'asyir, Muhammad Amir, Farid Ma'ruf dan Ustadz Wahyudin,. Abdullah Sungkar, Abu Bakar Ba'asyir menjadi sosok mewakili kelompok yang radikal, sedangkan Muhammad Amir, Farid Ma'ruf merupakan sosok moderat. Sosok Ustadz Wahyudin menjadi sosok yang berdiri di tengah diantara dua kecenderungan itu, di mana ada kombinasi para ustadz yang cenderung salafi dan dan yang cenderung moderat mewarnai lembaga pendidikan ini.

Hanya karena pendirinya yaitu Abdullah Sungkar dan Abu Bakar Baaseyir cenderung mengembangkan tradisi keagamaan yang berjarak dengan kekuasaan, maka citra Pesantren Ngruki yang berjarak dengan negara itupun terbangun. Walaupun diakui, semenjak Abdullah Sungkar dan Abu Bakar Baasyir berurusan dengan hukum karena sikap politik, dan pernah meninggalkan Indonesia untuk sekian waktu di Malaysia, praktis Pesantren Ngruki telah membenahi diri untuk hanya fokus pada tafaquh fiddin.

\section{Reproduksi Paham Keagamaan Pesantren Ngruki}

Keberadaan para pengasuh
Pesantren Ngruki yang sebagian salafi dan sebagian yang lain moderat menjadi fenomena unik dari pesantren ini. Kombinasi keduanya melahirkan lembaga pendidikan yang satu sisi berwarna salafi, namun sisi lain berwarna modern. Sisi salafi nampak dari jenis pemahaman al-Qur'an dan As-Sunnah dan menghindar dari bid'ah dan khurofat, sedangkan sisi modernnya Nampak dari tata kelola pesantren yang menggunakan managemen modern, yaitu tidak tergantung kepada figure sentral kyai dan dikelola dengan system organisasi modern.

Karena garis yang dipilih adalah posisi "non madzhab" maka Pesantren Ngruki tidak mau disebut sebagai pengikut salah satu paham yang ada Ada banyak label memang yang muncul kemudian terhadap pilihan Ngruki ini, ada yang menyebut wahabi, ada yang menyebut pesantren salafi, ada yang menyebutnya Islam puritan, bahkan ada yang mengkaitkan dengan kata radikal. Pengelola Pesantren Ngruki sebenarnya tidak ingin menanggapai semua tuduhan tersebut. Mereka ingin lebih focus pada sebagai lembaga Tafaquh Fiddin.

Dari model pemahaman keagamaan, Pesantren Ngruki dari awal membangun pandangan keagamaan yang bercorak "non madzhab", artinya tidak mengikuti madhzab keagamaan manapun. Pesantren Ngruki mencoba 
netral dari pandangan keagamaan manapun. Tradisi yang dibangun dari awal cenderung model paham "salafi." Kata "Salafi" disini dibedakan dengan jenis pesantren salafiyah. Istilah salafi dimaksudkan kepada paham kembali ke al-Qur'an dan al-Hadits dan sangat anti takhayul, bid'ah dan khurofat. Pilihanini dalam bacaan pengkaji, menjadikan Pesantren Ngruki ini menjadi simbol tipologi baru pesantren yaitu tipologi salafi. Belakangan jenis pesantren jenis ini telah muncul di berbagai daerah dengan pilihan corak keagamaan yang sama.

Pesantren Ngruki Ngruki semula dari sisi pembelajarannya mengambil model pembelajarandari beberapa pesantren yang menjadiasal tempatbelajar para tokohnya. Corak awal yang ingin dibangun Pesantren Ngruki minimal dari ketiga karakteristik lembaga pesantren, yaitu Pesantren Bangil, Pesantren Gontor dan dari sistem ekonominya ingin sedikit meniru pesantren al-Falah di Bogor. Dari sisi fikihnya mengikuti pola Persis (Bangil), dari sisi bahasanya mengikuti pola Gontor, dan dari sisi ketrampilannya ingin mengikuti al-Falah (Bogor). Dari tiga keinginan itu, nampaknya yang dapat terimplementasikan adalah dua yang pertama yaitu secara Fiqh cenderung tekstualis (pola Bangil) dan mempunyai kemampuan berbahasa arab dan Inggris (pola Gontor).

Pesantren Ngruki dalam buku profilnya dalam penyelenggaraan pendidikan bertujuan: 1) terbentuknya generasi Muslim yang siap menerima dan mengamalkan Islam secara kaffah; dan 2) mempersiapkan kehadiran ulama. Generasi muslim yang mengamalkan Islam yang kaffah itu ditandai dengan Salimul aqidah (generasi bertauhid murni yang mewarnai seluruh kehidupan); Sohihul Ibadah (beribadah dengan benar yaitu ikhlas lillahi ta'ala dan mengikuti contoh rosulullah), Matinul Khuluq (berakhlak mulia sebagaimana dicontohkan rosulullah), mutsaqoful fikri (berwawasan/berilmu pengetahuan yang luas), Qowiyul jismi (jasmani yang kuat dan sehat), Qodiran alal Kasbi (mempu hidup dengan mandiri, tidak menjadi beban orang lain), Nafi'an linafsi walighoirih (bermanfaat bagi diri dan orang lain), Mujahidan lidiinihi (mengerahkan seluruh potensinya untuk agamanya) (Profil Pesantren Al Mukmin, 2014: 20-21).

Karakteristik ini yang menyebabkan Pesantren Ngruki ini memilih corak beragama sebagaimana salafussolih (para pendahulu Islam/sahabat rosul yang solih). Pilihan mengutamakan aqidah yang benar dan ibadah sesuai sunnah yang benar merupakan penegasan Pesantren Ngruki dalam menentukan corak beragama. Pilihan itu juga yang menyebabkanNgrukimemilihgarisdalam warna Islam puritan. Pilihan ini tentu tidak salah, bahkan berikutnyapilihan itu menjadikan Pesantren Ngruki menjadi mainstream tersendiri dari model Islam kultural yang dipahami umat mayoritas di Indonesia. Mereka tidak membenarkan praktek ibadah yang kelihatan sinkretis dengan budaya lokal seperti tahlilan, nyadran, rebu pungkasan.

Pesantren Ngruki, menurut kacamata pengkaji terkait dengan peristiwa Bom Bali 2002 atau justru sudah digagas sebelumnya, sebenarnya sedang melakukan berbagai perubahan corak pendidikan. Beberapa perubahan yang sebenarnya sudah dirintis sejak tahun 1995 itu meliputi perubahanseperti perubahan kelembagaan, perubahan managerial, perubahan kurikulum, perubahan personalia.

Kelembagaan. Dari sisi kelembagaan, perubahan besar yang terjadi di Pesantren Ngruki adalah penggabungan beberapa lembaga pendidikan menjadi satu dibawah lembaga Pondok Pesantren Islam Al Mukmin (PPIM). Lembaga pendidikan diniyah yang dulu bernama KMI 6 
tahun disatukan dengan pendidikan formal MTs dan MA. Pesantren Ngruki mengikuti regulasi di mana lembaga pendidikan keagamaan harus tercatat dalam administrasi negara. Pesantren Ngruki saat ini berdiri telah berbadan hukum dengan izin operasional No. 79/2015 dengan nomorStatistik Pesantren: 510033110015, tertanggal 3 Sept 2015. Ini menunjukkan bahwa pesantren ini telah mengikuti ketentuan penyelenggaraan lembaga pendidikan secara resmi di Indonesia.

Perubahan lain secara kelembagaan selain penggabungan KMI dengan madrasah reguler, adalah dibukanya program Sekolah Tinggi Agama Islam al Mukmin (STIM). Prodi yang dibuka adalah prodi bahasa Arab. Perguruan tinggi ini selain memfasilitasi alumni Pesantren Ngruki yang ada, juga melayani untuk masyarakat umum. Embrio sekolah tinggi ini adalah program ma'had Aly yang muncul seiring wacana rintisan Ma'had Aly di lingkungan pesantren, yang pernah digagas juga oleh Pesantren Ngruki.

Managemen. Seiring perjalanan waktu, Pesantren Ngruki juga mencoba memodernisir managemen pesantren. Kalau sebelumnya pesantren Ngruki mengandalkan sistem yang berpusat pada pimpinan pondok, maka pada tahun 2006, Pesantren Ngruki mencoba menerapkan sistem managemen yang modern yang bertumpu pada sistemsebagaimana yang dikembangkan oleh Pesantren modern Assalam di Sukoharjo. Managemen tidak lagi bertumpu pada kepemimpinan perorangan, namun dilembagakan dalam bentuk sistem sedemikian rupa yang membuka tingkat keterbukaaan managemen. Maka secara managemen, saat ini Pesantren Ngruki sudah tidak berbeda dengan Pesantren modern Assalam (wawancara dengan Kadarusman).
Kurikulum. Dengan mengikuti sistem pendidikan yang dikembangkan olehKementerianagamayangberdasarkan kurikulum pendidikan formal sejak menyelenggarakan pendidikan madrasah sejak tahun 1979, maka secara garis besar kurikulum yang diajarkan semuanya mengandalkan pertemuan di kelas reguler. Dahulu ketika Pesantren Ngruki masih menyelenggarakan KMI, maka mata pelajaran sepenuhnya dikembangkan oleh pesantren al Mukmin. Maka sekarang, karena mengikuti sisten pendidikan formal, maka baha-bahan ajar sepenuhnya mengikuti sistem yang dikembangkan kementerian agama. Pengayaan materi agama berada di bawah bayang-bayang keberhasilan pendidikan formal yang diselenggarakan pesantren. Hal ini disadari oleh para pengelola, adanya penurunan mutu dari para santri Pesantren Ngruki.

Selain itu, dalam rangka pengembangan keunggulan lokal, pesantren Ngruki membuka program tahfid bagi santri-santrinya. Program ini dibuat sebagai salah satu ciri keunggulan yang ingin dimiliki pesantren ini. Program ini dibuka di tempat utara.

Personalia. Dengan diterapkan sistem pendidikan formal, maka para pengajarnya pun beralih dari dahulu kebanyakan adalah para alumni KMI, seiring tuntutan sertifikasi, maka para gurupun dicarikan minimal yang lulusan S1 dari perguruan Tinggi yang ada. Maka seiring kebutuhan itu, pengasuh yang lulusan KMI menurun drastis.

Sebagai media informasi untuk bacaan para santri dan media informasi antar para pengajar, Pesantren Ngruki menerbitkan dua majalah yaitu majalah Asy Syamil untuk media informasi para pengajar, dan majalah al Mukminun untuk bacaan para santri. Melalui media majalah ini pandangan dan dinamika pesantren Ngruki diinformasikan baik untuk konsumsi internal secara khusus, 
dan juga konsumsi luar bagi yang membutuhkan.

Corak pendidikan Pesantren Ngruki, sekalipun di bawah bayangbayang tuduhan radikal pasca bom Bali 2002, namun pesantren ini telah melakukan langkah-langkah perubahan untuk menjadi pesantren yang lebih modern. Menurut pengelola pesantren, mereka tidak memungkiri bahwa semangat para pendiri yang ingin mengajarkan Islamkaffah menjadi warna dan spirit tersendiri bagi Pesantren Ngruki. Suka atau tidak suka, mereka merupakan sosok yang menjadi latar belakang sejarah lembaga pendidikan ini. Walaupun beberapa pemikiran ekstrim tertentu yang mereka tidak sepenuhnya setuju seperti gagasan negara Islam dan baiat kepada ISIS, namun mereka para pendiri tetaplah pendiri. Warna belakangan PesantrenNgruki, terhadap Gagasan IslamKaffah, mereka tetap mempertahankan, sementara gagasan ekstrim yang dicontohkan para pendirinya tidak atau belum tentu diikuti. Apalagi setelahada tuntutan lembaga pendidikan harus mempunyai badan hukum secara formal dan harus menyatu dengan sistem kenegaraan Indonesia.

Hanya saja Pesantren Ngruki Solo dengan sikap politik tokoh-tokohnya di masa lalu yang berseberangan dengan pemerintah pada saat itu dan pilihan netral dari madzhab tertentu dan kecenderungan terhadap paham yang menghindari bid'ah dan khurofat menjadi pesantren al Mukmin tidak bisa lepas dari pelabelan-pelabelan itu. Dari sisi paham keagamaan Nampak Pesantren Ngruki menganut paham yang cenderung salafi.

Paham salafi dari beberapa literatur disebutkan bahwa pada awalnya paham ini lebih cenderung sebagai paham dan gerakan daripada jenis lembaga pendidikan. Dari sisi paham dan gerakan, mengutip Muhammad Ihsan menyebut 4 ciri utama salafi, yaitu: 1) Hajr Mubtadi' atau pengisoliran terhadap pelaku bid'ah; 2) gerakan salafi bukanlah gerakan politik praktis, bahkan terkadang mereka memandang keterlibatan dalam semua proses politik praktis seperti pemilihan umum merupakan sebuah penyimpangan; 3) walaupun ada perbedaan pendapat di kalangan salafi, ciri berikutnya sikap tertentu terhadap gerakan Islam lain; 4) ketidakbolehan khuruj atau melakukan gerakan separatisme dalam sebuah pemerintahan Islam yang sah(Muhammad Ikhsanhttp:// wahdah.or.id/Akses 24 Mei 2016)

Ciri-ciri agak lengkap disebutkan oleh Andi Anderus dalam bukunyaKarakteristik Pemikiran Salafi di Tengah Aliran-Aliran Pemikiran KeIslaman (2011). Menurutnya, pemikiran gerakan salafi dapat dikategorikan dalam beberapa permasalahan. Pertama, dalam masalah i'tiqadiyyah (asas agama). Dalam masalah ini, salafi memegang prinsip: 1) Menjadikan wahyu sebagai prioritas utama dalam memahami masalah i'tiqadiyah;2) Menghindari ta'wil tafsili; dan 3) Memaparkan ajaran aqidah berdasarkan Al-quran. Kedua, dalam prinsip beragama. Dalam aspek ini, terdapat beberapa prinsip yang diyakini oleh kelompok salafi, yaitu: 1) Memandang agama Islam sebagai satu kesatuan yang tak terpisahkan; 2) Menjadikan cara beragama ulama salaf sebagai patokan dalam pemahaman dan peribadata, serta menganggap cara peribadatan seperti inilah yang benar; dan 3) Banggadan yakin dengan keIslaman-nya.Ketiga, dalammasalahfur u'iyyah,kelompok salafi membedakan antara syar'iy munazzaldan syar'i mutaawwal. Dan keempat, konsep jalan tengah. Kelompok salafi senantiasa berprinsip la tafrita wala ifrat (Adi Anderus, 2011).

Pemahamansalafiyang tadinyalebih untuk menyebut gerakan, di kemudian hari label yang sama digunakan juga 
untuklembaga pendidikan pesantren. Salah satunya tipologi yang disebutkan oleh zainal Arifin menyebutkan bahwadi tengah-tengah masyarakat, istilah pesantren Salafi biasanya digunakan oleh kelompok reformis untuk memberikan penekanan pada pesantren yang secara konsisten mengikuti ajaran ulama Salafush Sholih, yaitu sejak zaman para sahabat, tabi'in, dan tabi'it tabi'in. Sedangkan untuk kelompok umat Islam tradisionalis, biasanya lebih suka menggunakan istilahpesantren SalafatauSalafiyyah, karena image pesantren Salafi lebih dekat dengan pemahaman Islam yang literal. Atau untuk membedakannya, penulis memberikan istilah Salafi-Modernisbagi pesantren Salafi kaum reformis dan SalafiTradisionalis bagi pesantren tradisional (Zainal Arifin, 2012: 40-53).

Bagaimana posisi Pesantren Ngruki bila dihadapkan dengan ciriciri itu. Ternyata tidak semua pihak berani memasukkan Pesantren Ngruki sebagai pesantren Salafi. Contohnya tulisan di website Pondok Al Khoirot Malang yang berjudul "Beda Pondok Modern, Pesantren Salaf dan Pesantren Salafi" dengan membuat36 contoh pesantren salafi, ternyata tulisan ini tidak memasukkkan Pesantren Ngruki dalam kategori ini. Padahal tulisan ini menyebutkan beberapaciri pesantren yang disebut pesantren Salafi. Dari sekian ciri sebagian menurut pengamatan pengkaji diikuti dan menjadi arus utama pembelajaran agama di Pesantren Ngruki.

Tulisan dalam website Pondok Al Khoirot Malang (http://www.alkhoirot. com/ akses 24 Mei 2016)menyebutkan ciri pesantren yang termasuk kategori pesantren salafi, yaitu sebagai berikut:

- Doktrin tauhid sebagaimana yang diajarkan oleh Muhammad bin Abdul Wahab, pendiri Wahabi yang mengambil inspirasi dari Ibnu Taimiyah. Salah satu ciri khasnya adalah pembagian tauhid menjadi tiga yakni tauhid rububiyah, tauhid uluhiyah, dan tauhid al-asma was shifat.

- Dalam bidang fikih umumnya merujuk pada madzhab Hanbali. Yang salah satu ciri khasnya yang menonjol adalah tidak ada qunut waktu shalat subuh, dan tidak najisnya kotoran hewan. Walaupun dalam bidang tertentu seperti soal talak dan tawasul mereka berbeda pendapat dengan mazhab Hanbali.

- Dalam persoalan hukum baru, mereka merujuk pada pandangan ulama fikih kontemporer mereka yaitu Abdullah bin Baz, Ibnu Uthaimin, Al-Bani (dalam soal hadits), Al-Fauzab. Banyak dari utama Wahabi yang cenderung bermazhab Zhahiri, yaitu mazhab yang tidak mengakui adanya qiyas sebagai salah satu sumber hukum Islam.

- Dalam bidang tauhid, mereka mengikuti doktrin Ibnu Taimiyah yang dikenal sebagai kaum mujassimah (menganggap Allah itu punya fisik dan bertempat tinggal seperti makhluk) suatu pandangan yang menurut ulama Ahlussunnah Wal Jamaah dianggap sesat.

- Menyebarkan ajaran yang mereka klaim sebagai“"kemurnian Islam" seperti era Salafus Sholeh dan mengeritik keras praktik umat Islam yang dianggap tidak murni dengan label bid'ah, syirik, kufur.Suatu klaim yang tidak berdasar. Yang benar adalah ajaran mereka bukan meniru Salafussoleh, tapi meniru Ibnu Taimiyah dan Muhammad bin Abdul Wahab yang terakhir ini baru lahir pada abad ke-18 masehi.

- Praktik yang dianggap bid'ah dan syirik oleh Wahabi antara lain tahlil, ziarah kubur, peringatan Maulid Nabi, peringatan Isra' Mi'raj, peringatan 1 Muharam, dll. 
- Menolak kritik dari luar dan menyebut pengeritiknya sebagai Syiah Rafidhah atau konspirasi Zionisme Yahudi atau Freemason.

- Ada dua tipe Salafi Wahabi yaitu Wahabi Arab Saudi dan Wahabi Yaman.Wahabi Arab Saudi cenderung pro pemerintah yang berkuasa sedang Wahabi Yaman cenderung anti-pemerintah dan lebih radikal. Kelompok teroris banyak berasal dari didikan Salafi Yaman ini di bawah pimpinan Muqbil Al-Wadi'iy. Sementara, Wahabi pro Arab Saudi bersikap sebagai simpatisan terhadap Wahabi Yaman.

Pengkaji sendiri darikecenderungan utama yang dipraktekkan di Pesantren Ngruki di satu sisi, dan di sisi lain bila dihadapkan pada 3 kategori arus utama jenis pesantren, yaitu pesantren tradisional (sering dibaca pesantren salaf), pesantren modern (pesantren khalaf) dan pesantren dengan jenis pesantren yang cenderung ke paham pemurnian agama dan menolak praktek sinkretisme (pesantren salafi), maka pengkaji lebih cenderung mengelompokkan Pesantren Ngruki lebih banyak ke bentuk ke tiga, yaitu pesantren salafi.

Saat ini Pesantren Ngruki telah melahirkan alumni yang banyak. Ada sebagian alumni yang prihatin dengan perkembangan Pesantren Ngruki yang menurutmereka menurun kualitasnya. Sebagian yang merasa prihatin mencoba menggagas pesantren yang lebih salafiy lagi.Sebagai corak baru, yaitu pesantren puritan atau "Salafi," para alumni mendirikan lembaga pendidikan yang sejenis (Salafi) di berbagai tempat seperti Darus Syahadah (Boyolali), Darul Wahyain (Magetan). Apakah mereka saling berhubungan atau tidak, tetapi yang terjadi mereka umumnya mengembangkan corak yang sama yaitu pesantren salafi.
Perkembangan paling mutakhir, Pesantren Ngruki mengakomodasi kurikulum Kementerian Agama yang diakuipara alumni santri Ngruki nuansa tafaquh fiddinnya mulai berkurang, menyebabkan beberapa alumni pesantren ingin mendirikan pesantren yang salafi atau lebih ideal lagi. Ada yang menyelenggarakan pendidikan formal, ada juga yang menyelenggarakan pendidikan nonformal. Beberapa pesantren memang mengambil polaSalafi. Tidak dipungkiri bahwa perkembangan Pesantren Ngruki saat ini lebih akomodatif, dan hal itu menyebabkan beberapa alumni untuk membikin pesanten yang lebih salafi lagi.

Bukti perubahan juga nampak pada upaya yang dibangun Pesantren Ngruki yang menjaga hubungan baik dengan Pemerintah. Setiap tamu dari pemerintah yang melakukan silaturahmi ke Pesantren Ngruki dihormati sebagaimana tamu yang lain. Demikian juga dengan kementerian agama, Pesantren Ngruki selalu memenuhi undangan pembinaan yang dilakukan kementerian Agama Sukoharjo. Beberapa persyaratan penyelenggaraan pendidikan seperti badan hukum, kesetiaan terhadap konsep NKRI diikuti sedemikian rupa oleh Pesantren Ngruki.Pesantren Ngruki juga tidak lagi bermudah-mudah melakukan takfiri terhadap kelompok keagamaan lain. Menurut Ustadz Wahyudi, pemahaman takfiri tidak diajarkan dalam agama Islam. Karena itu tidak boleh umat Islam melakukan takfiri terhadap kelompokumat Islam yang lain.

Keberadaan Pesantren Ngruki dengan pilihan pemahaman agama yang puritan, saat ini telah menjadi simbol keberadaan corak pesantren puritan di Indonesia. Kalau dahulu Islam puritan disimbolkan sebatas kehadiran gerakangerakan sosial seperti kaum Paderi di Sumatera Barat, demikian juga di Pulau 
Jawa diwakili oleh keberadaan Persis di Bandung, Al Islam di Solo, Darul Hadits di Bangil Kediri. Maka saat ini, Islam puritan telah hadir dalam lembaga pendidikan yang dulu menjadi basis Islam tradisional, yaitu pesantren.

\section{Respon Pesantren Ngruki terhadap Stempel Radikal}

MelihatfenomenaPesantrenNgruki, muncul pertanyaan apakah pesantren ini termasuk lembaga pendidikan yang cenderung mengembangkan paham Islam radikal? Menjawab pertanyaan itu kita perlu menelusuri subtansi kpaham keagamaan yang diajarkan, dari mana kesan radikal itu muncul, dan bagaimana kondisi sekarang yang berlaku di pesantren tersebut. Dari situ kita bisa lebih proporsional memahami karakter Pesantren Ngruki.

Kesan Pesantren Ngruki radikal muncul dari beberapa sebab seperti: 1) pandangan sebagian pendiri (Abdullah Sungkar dan Abu Bakar Baasyir) yang terkadang berbeda dengan mainstream umat seperti tidak mau menghormat bendera negara, menolak asas tunggal, baiat pada ISIS (Walau yang terakhir ini diragukan oleh kalangan internal pesantren Al Mukmin); 2) perilaku sebagian kecil alumni yang terlibat pada tindakan terorisme atau jaringan internasional yang cenderung membenarkan tindak kekerasan untuk menegakkan agama; 3) walau sifatnya penafsiran luar, praktek pembelajaran di pesantren yang sering dikaitkan sebagai pensemaian paham radikalisme. Dari kesan-kesan ini, kemudian orang luar mudah menuduh Pesantren Ngruki sebagai pesantren radikal.

Bagaimana pengaruh kesan radikal bagi peserta didik atau alumni Pesantren Ngruki?secara umum dari hasil wawancara dan pengamatan pengkaji santri Pesantren Ngruki tidak HARMONI | Januari - Juni 2017 terganggu dengan kesan itu. Bagi mereka, konsekwensi mengamalkan Islamkaffah sudah pasti akan berhadapan dengan berbagai tuduhan. Kesan radikal salah satunya. Namun tidak sedikit juga yang menjelaskan bahwa pesantren mereka sebenarnya lebih mengajarkan paham agama salafie, bukan radikal. Paham salafie atau puritan hanya ingin memahami agama sebagaimana yang diajarkan rosulullah sebagaimana pola salafusolih. Mereka tidak akan memaknai secara baru sebuah istilah agama, kalau makna baru itu cenderung menghapus makna leterlijk nya.

Sebagai contoh, ketika mereka memaknai "jihad."Jihad menurut warga Ngruki, seperti itu jihad bermakna "qital" (perang) yaitu Jihad melawan orang yang memerangi orang Islam. Karena itu bila ada belahan dunia di mana ada umat Islam yang didhalimi oleh orang lain, di sana penggilan jihad itu ada. Apabila ada makna jihad yang lain seperti bahwa dalam setiap tindakan baik perlu jihad, dan jihad dalam masa kontemporer bukanlah perang, maka mereka berkeberatan pemaknaan seperti itu. Jihad boleh dimaknai di medan lain (di luar perang), tetapi jihad juga mempunyai makna harus siap perang. Maka apabila ada belahan bumi Indonesia ada ancaman nyata kepada umat Islam, maka kewajiban jihad itu ada.

Terhadap kesan bahwa ada alumni Ngruki yang terlibat dalam organisasi terorisme, pihak pengasuh pondok menyatakan bahwa itu tanggungjawab yang bersangkutan. Keterlibatan itu lebih banyak terjadi di luar pondok. Dalam kacamata pesantren Ngruki, tindakan-tindakan sporadis seperti bom bali, bom mariot, bom Sarinah adalah sebuah kesalahan atau penyimpangan dari pemaknaan jihad, karena di situ umat Islam tidak sedang menjadi obyek serangan dari pihak lain. Apalagi dalam peristiwa-peristiwa semacam itu, ada 
kemungkinan korban yang meninggal justru dari pihak kaum muslimin sendiri (wawancara dengan Ustadz Wahyudin).

Kalau melihat paham keagamaan yang dikembangkan Pesantren Ngruki saat ini, maka kita akan melihat bahwa mereka mulai melakukan kompromikompromi tingkat tertentu. Sebagaimana semboyan mereka, mereka ingin berdiri di tengah umat yang beragam, karena itu dia lebih menekankan paham keagamaan yang kembali ke Al-Qur'an dan Assunnah (model salafiy). Dari sisi pemahaman teologi, Pesantren Ngruki mengajarkan aqidah ahlusunnah wal jamaah. Kurikulum yang diajarkan menurut mereka seiring dengan kurikulum yang dianjurkan oleh kementerianAgama. Ketika kita mencermati buku pelajaran yang diajarkan di bidang aqidah, maka kita akanmenemui kitab-kitab seperti Kitab Al Iman (Abd Majid Az Zindani), Kitab Tauhid (Solih Fauzan), dan bukubuku aqidah yang diterbitkan oleh Kementerian Agama.

Misi utama pesantren Al Mukmin, sebagaimana pengakuan mereka, mereka tetap ingin melahirkan kader mujahid dan cendekia, Mengajarkan IslamKaffah, dan masih mempertahankan kehatihatian segala sesuatu yang bernuansa takhayul, Bid'ah dan Khurafat (TBC). Hal ini terlihat dari pandanganan para pengasuh yang tidak melayani upacara kenduri atau tradisi-tradisi lokal yang nampak percampuran dengan agama. Pesantren Ngruki melalui kipprah para ustadz dan para santrinya melakukan sosialisasi paham keagamaannya ke masyarakat sekitar pondok. Salah satu program yang digerakkan oleh pondok adalah membina majlis-majlis taklim sekitar.ingin membina majlis taklim di masyarak at di Solo dan sekitarnya, Al Mukmin mengirim alumni jurusan keagamaan ke berbagai daerah sebagai bentuk pengabdian selama 1 tahun

\section{Pesantren Ngruki dalam Pergumulan Ideologi Transnasional}

Pada tahun 2016, ketika bom bunuh diri mengatasnamakan jihad Islam terjadi di depan Gedung Sarinah Jalan Thamrin Jakarta Pusat, maka luka lama Pesantren Ngruki terjadi lagi. Setiap ada peristiwa yang dianggap tindakan teroris, publik dan media sering melihat lagi bagaimana Pesantren Ngruki saat ini. Dalam kondisi seperti ini, Pesantren Ngruki tidak bisa tidak harus kembali menghadapi berbagai tuduhan yang ada. Pesantren Ngruki Solo pasca peristiwa Bom Bali menjadi sorotan dunia terkait keterlibatan beberapa alumninya dalam peristiwa tersebut dan beberapa peristiwa "radikal" sesudahnya. Kondisi ini menempatkan seakan Pesantren Ngruki sebagai pengibar bendera Islam radikal di Indonesia. Bagaimana kirakira kita membaca fenomena ini, atau bacaan seperti apa untuk menilai secara proporsional lembaga pendidikan Pesantren Ngruki Solo saat ini?

Dalam berita sebuah harian yaitu Republika (7/2/2016) memberitakan bahwa Al Mukmin Ngrukitolak klaim radikal. Ketua Pembina Yayasan Al Mukmin, $\mathrm{KH}$ Muhammad Amir, mengatakan, PesantrenNgruki memiliki sejarah yang lama. Amir merasa, Pesantren Ngruki selalu disudutkan setiap muncul peristiwa teror. "Saya itu menjadi pengasuh pesantren Ngruki sejak 1960-an. Sampai sekarang menjabat Ketua Pembina Yayasan. Lha kok serba disalahkan. Kalau ada persistiwa teror, Ngruki selalu dikaitkaitkan, " ujar Amir di Surakarta. Dia menegaskan bahwa Pesantren Ngruki adalah murni lembaga pendidikan dan dakwah. Ia menegaskan, sejak masuk ke lembaga ini dan hingga saat ini tidak ada kurikulum Pesantren Ngruki yang mengajarkan kekerasan.

Dalam paparan sebelumnya pengkaji berdasarkan informasi pengelola lembaga pendidikan Pesantren Ngruki 
bahwa mereka hanya menjalankan usaha pendidikan untuk tafaquh fiddin. Mereka juga tidakmengajarkan radikalismedalam beragama. Karena itu siapa atau pihak mana yang paling bertanggungjawab bila ada alumni Pesantren Ngruki terlibat dalam peristiwa-peristiwa yang dianggap sebagai tindakan teror seperti itu? Untuk memahami hal itu, pengkaji merasa perlu membaca konteks pergerakan Islam di Kota Surakarta dan sekitarnya.

Sejarah sosial di Surakartasebelum Indonesia Merdeka memegang peranan penting dalam pergumulan ideologi di tanah air. Banyak gerakan dan tokohtokoh ideolog berkelas nasional atau bahkan regional Aseanpernah hidup di kota Surakarta ini, sebut saja H. Samanhudi dengan Serikat Dagang Islam (SDI), Tan Malaka pernah hidup di kota itu. Maka tidak heran kalau ada anggapan bahwa Solo adalah pusat ideologi bahkan dianggap pusat spiritual Jawa, karena di sanalah dahulu menjadi pusat lahirnya berbagai pemikiran dan tokoh perubahan di jawa. Dari Solo pula pernah lahir gagasan asosiasi pedagang muslim SDI yang nantinya bertransformasi menjadi kekuatan politik dengan berubah menjadi Sarekat Islam (SI).

Sempat terfikir dalam benak pengkaji, sejak kapan Solo menjadi arena pergumulan ideologi secara terbuka, yang nuansa masih terasa hingga sekarang. Walaupun kota surakarta adalah kota yang relatif tidak terlalu besar, namun bergumulan ideologis terasa kencang. Dua atau lebih kelompok ideologis bernuansa keagamaan terpampang secara terbuka seperti penjualan daging anjing di masyarakat. Di wilayah-wilayah yang penduduk muslim lebih besar, penjuangan daging anjing secara terbuka biasanya jarang ditemukan. Namun di Solo, malahan secara resmi penjualan daging anjing dilegalkan dengan istilah "Jual Sate Gukguk." Sesuatu yang jarang ditemukan di daerah lain.
Lain Surakarta, lain pula Yogyakarta. Sebagaisesama kota yang pernah menjadi pusat kerajaan Jawa, dinamika antara kedua kota nampak nyata berbeda. Surakarta sebagai kraton nampaknya agak berbeda nasib dalam mentransformasikan diri dan tetap menjadi simpul sosial jawa dalam sistem perpolitikan nasional modern. Sementara Yogyakarta begitu Indonesia merdeka langsung dapat mnengambil posisi yang pas dan langsung menyatakan bergabung ke RI sehingga daerah itu mendapatkan status daerah istimewa. Sementara Surakarta nampaknya terlalu larut polemik dalam berbagai ideologi dan peran kraton yang lemah sebagai simpul kesadaran masyarakatnya, sehingga Kraton Surakarta tidak mendapatkan status sebagaimana Yogyakarta.

Pergumulan ideologis secara terbuka di Surakarta, menurut pengkaji, terjadi semenjak Solo menjadi kota kosmopolitan di Indonesia. Ketika Belanda dengan VOC nya menetapkan Batavia sebagai pusat kendali daerah jajahan di Hindia Belanda, maka politik lokal Indonesiaberpusat padakekuasaan Mataram.kalau sebelumnya pernah kekuasaan mataram di Jogja, yaitu ketika Sultan Agung mampu memobilisir pribumi untukmengusir Belanda dari Batavia, maka kemudian pusat mataram pada waktu berikutnya berpindah ke Solo. Menjalang kemerdekaan RI atau awal abad ke 20, maka bersemailah berbagai ideologi transnasional seperti munculnya kesadaran nasionalisme yang diikuti perkembangan paham komunisme. Maka Solo menjadi kota pertama di Indonesia yang menjadi tempat persemaian ideologi dunia saat itu. Sejak saat itu Surakarta menjadi daerah dengan pergumulan berbagai ideologi.

Surakarta menjadi kota yang tidak seberuntung sebelahnya Yogyakarta setelah Indonesia merdeka. Begitu merdeka, yogyakartamendapat status 
daerah istimewa dan berhasil membangun diri menjadi kota budaya dan pendidikan, sementara Solo tidak mendapatkan status itu. Alih-alih Solo malah terlena dengan pergumulan ideologi yang berkepanjangan. Keprihatinan inilah yang memunculkan kemudian perasaan kekhawatiran di kalangan muslim di Surakarta pada tahun 1970-an yang merasakan umat Islam di ndonesia setelah merdeka seakan terpinggirkan. Maka sejak itu muncul pemikiran untuk membangun kembali Islam di Solo denga mendorong kembali ke Al-Qur'an dan As-Sunnah untuk menemukan kembali kejayaan Islam. Semangat itulah yang nantinya melahirkan tokoh yang dianggap mengajarkan Islam puritan di Solo yang dikenal dengan Trio Abdullah (Mutoharun Jinan, 2014).

Pergumulan ideologi ini, menurut aktivis yang penulis temui bahwa Solo telah menjadi transit berbagai ideologi baik nasional maupun global. Pergumulan ideologi terasa kuat karena masingmasing ideologi mempunyai agen di kota ini. Atau dengan kata lain, di kota itu terdapat agensi yang kuat yang mengawal berbagai ideologi transnasional itu. Agak paradoks memang, ketika Solosecara geografis adalahkota yang kecil, kenapa pergumulan ideologi menjadi sedemikian kuat dan vulgar. Makamenurut informan yang kami temui,karena di Surakarta banyak terdapat agen lokal yang masingmasingnya mencoba memelihara ideologi tyang diyakininya. Sponsornya tetap jejaring yang sifatnya nasional atau malahan internasional.

Pesantren Ngruki menjadi salah satu pilar yang mencoba menegakkan ideologi Islamisme dalam wajah puritan. Di Surakarta dan sekitarnya, Pesantren Ngruki ternyata tidak sendirian menegakkan Islamjenis puritan ini. Di sanaterdapat beberapa lembaga pendidikan yang senada dengan misi Islam puritan ini, seperti Majelis Tafsir Al-Qur'an (MTA), Majlis Taklim Gumuk,
Lembaga Dakwah Islam Indonesia (LDII). Berbagai lembaga pendidikan ini mempunyai corak gerakan kembali ke Al-Qur'an dan Hadits, dan cenderung menghindari tasawuf. Mereka berhujah bahwa banyak umat Islam sekarang telah melakukan percampuran Islam dengan budaya-budaya lokal. Karena itu dakwah menurut mereka adalah mengembalikan umat pada ajaran yang benar.

Sebatas gerakan ideologis dengan wajah Islam puritan sebenarnya tidak ada masalah. Yang menjadi masalah adalah di Surakarta telah ada perkembangan ideologi Islam trans nasional yang menghalalkan tindakan teror kepada mereka yang dianggap musuh. Hal inilah dalam bacaan pengkaji, bahwa persemaian paham radikal yang terjadi pada sebagian kecil alumni santri terjadi setelah keluar dari Pesantren Ngruki dan bergaul dengan agensi-agensi ideologi trannasional yang ada di kota itu. Ismail Noor Huda dalam bukunya Temanku Terorismenyimpulkan, bukan Ngruki yang membentuk seorang santri jadi teroris, tetatpi oleh lingkungannya (Noor Huda Ismail, 2010).

Narasi ini diakhiri dengan pandangan pengkaji bahwa Pesantren Ngruki tidak bisa dianggap yang paling bertanggungjawab dengan adanya alumninya yang menhalalkan tindakan radikal, namun juga karena konteks sosial serta pergumulan ideologi yang kuat dalam sejarah sosial di Surakarta. Para alumni yang terlibat dalam tindakan teror atau jaringan organisasi transnasional lebih banyak terjadi pada diri individu alumni dan interaksi individu setelah mereka keluar dari pesantren, dan itu disebabkan oleh klik-klik sosial yang ada di wilayah Surakarta.Klik-klik itu ada sebagai bagian dari interest ideology, dan tidak menutup kemungkinan politik, yang masih menjadikan Surakarta dan sekitarnya sebagai panggung kontestasi ideologi transnasional. 


\section{Simpulan}

Dari paparan di atas ada beberapa kesimpulan yang perlu digaris bawahi: pertama, paham keagamaan tertentu seperti Islam keras, Islam radikal pada pesantren Ngruki tidak bisa dilepaskan dari konteks sosial dan historis yang membentuknya. Demikian juga kesan Islam radikal yang dituduhkan kepada pesantren Ngruki juga tidak bisa dilepaskan dari konteks sosial dan historis kotaSurakarta sebagai pusat pergumulan ideologi nasional sebelum Indonesia merdeka; kedua, terhadap tuduhan radikalisme pada pesantren Ngruki, para pengelola menganggap hal itu sebagai fitnahan yang harus diterima sebagai konsekwensi dari pendidikan Islam secara kaffah yang mereka ajarkan dan imbas sejarah ideologi di kota tersebut; ketiga, Setelah peristiwaBom Bali 2002, Pesantren Ngruki memang telah mengalami beberapa perubahan seperti orientasi, manajemen, kurikulum dan sebagainya. Namun beberapa perubahan ini sebenarnya telah digagas jauh sebelum peristiwa bom Bali, sehingga kejadian bom Bali bukanlah pemicu (triger) utama dari beberapa perubahan orientasi pesantren ini.Keempat, perubahanperubahan yang terjadi di pesantren Ngruki merupakan kompromi dari orientasi salafi di satu sisi dan orientasi khalafi di sisi lain dari para pengelola lembaga pesantren ini dan tuntutan perubahan yang menghendaki perubahan managemen lembaga pendidikan.Kelima, dari sisi reproduksi paham keagamaan di Pesantren Ngruki, merujuk perspektif Althusser yang dijadikan kerangka konsep yang digunakan dalam penelitian ini, reproduksi paham di pesantren ini dapat dimasukkan dalam kategori perubahan dalam model Ideological State Aparatus (ISA), yaitu perubahan yang cenderung persuasif yang bekerja melalui tafsir agama, media dan pendidikan.

Penelitian ini merekomendasikan: pertama, perlu kearifan khusus dari pemerintah dan akademisi dalam membaca corak pesantren ini dalam rangka melibatkan mereka berpartisipasi dalam pembangunan nasional, dan tidak justru mencurigai lembaga pendidikan keagamaanjenisinisebagaipesantrenyang mengajarkan kekerasan dan terorisme. Kedua, mengingat Ngruki merupakan salah satu tipologi baru perkembangan corak pendidikan pesantren di tanah air, dalam hal ini pesantren corak salafi, maka perlu kajian lanjut untuk lebih memahami dan memetakan perkembangan jenis pesantren ini di berbagai daerah di Indonesia dan peranannya dalam perubahan sosial.

\section{Ucapan Terima Kasih}

Atas telah selesainya penulisan dan pembahasan tulisan ini, penulis merasa perlu berterima kasih kepada Kepala Puslitbang Pendidikan Agama dan Keagamaan yang telah menugaskan kepada penulis untuk mengkaji perihal pesantren Ngruki. Ucapan terima kasih juga kemi perlu sampaikan kepada pengasuh Pesantren Ngruki yang telah kooperatif melayani pengkaji dalam menjawab beberapa pertanyaan.

\section{Daftar Pustaka}

Althusser, Louis. Tentang Ideologi: marxisme strukturalis, psikoanalisis, cultural studies. Yogyakarta: Jalasutra.2008

Anderus. Andi. Karakteristik Pemikiran Salafi di Tengah Aliran-Aliran Pemikiran KeIslaman, (Jakarta: Kementerian Agama, 2011). 
Arifin, Zainal. Perkembangan Pesantren Di Indonesia (Salafi, Khalafi, Modern, Dan Ma'had 'Aly), Jurnal Pendidikan Agama Islam Fakultas Ilmu Tarbiyah dan Keguruan, UIN Sunan Kalijaga Yogyakarta pada Vol.IX No.1 Juni 2012, hlm.40-53)

Asroni, Ahmad. 2012. Islam Puritan Vis A Vis Tradisi Lokal: Meneropong Model Resolusi Konflik Majelis Tafsir Al-Qur'an Dan Nahdlatul Ulama Di Kabupaten Purworejo, makalah Annual Conference International on Islamic Studies XII.

Asyhuri. Pendidikan di Pondok Pesantren Al Mukmin Ngruki Sukoharjo (Telaah Kurikulum dan Model Pembelajaran). Yogyakarta: Disertasi S3 UIN Sunan Kalijaga Yogyakarta, 2013.

Fuaduddin, dkk., Pondok Pesantren Islam Al Mukmin Ngruki Solo, (Jakarta: Puslitbang Pendidikan Agama dan Keagamaan, 2004).

Hisjam, Muhammad, Latar Belakang Pluralisme di Surakarta. https://muhhisyam. wordpress.com /2012/12/28/ akses 28 Maret 2016. Soepriyadi. Ngruki \& Jaringan Terorisme: Melacak Jejak Abu Bakar Baasyir dan Jaringannya dari Ngruki Sampai Bom Bali. (Jakarta: PT Al Mawardi Prima, 2003.

Ikhsan,Muhammad. Gerakan Salafi Modern di Indonesia Sebuah Upaya Membedah Akar Pertumbuhan dan Ide-Ide Substansialnya, Sumber Tulisan: http://wahdah.or.id/ gerakan-salafi-modern-di-indonesia/dikutip tanggal 24 Mei 2016.

Ismail,Noor Huda.Temanku Teroris, Jakarta: Penerbit Al Hikmah, 2010.

Jinan, Mutohharun. Melacak Akar Ideologi Puritanisme Islam: Survei Biografi atas "Tiga Abdullah", Jurnal Walisongo,Volume 22, Nomor 2, November 2014

Nurhasanah, Yuli. 2013. Pondok Ngruki dan Issu Terorisme dalam Pergumulan Wacana public: Studi Kasus Persepsi dan motivasi Orang Tua Terhadap pemilihan Pesantren sebagai tempat Pendidikan Anak. (belum dipublikasikan).

Zainuddin, Almuntaqo. Gerakan Purifikasi Islam di Surakarta (Studi tentang Al Islam 192601960), Yogyakarta: Tesis S2 UIN Sunan Kalijaga, 2009, h.

Sekilas Profil Pondok Pesantren Islam Al Mukmin, Sukoharjo: Humas PPIN, 2014.

Pasang-Surut Santri Pesantren Ngruki Pascabom Bali, http://news.okezone.com/ Selasa, 18 September 2012Akses 22 Maret 2016

Al Mukmin Ngruki Tolak Klaim Radikal, http://www.republika.co.id/berita /koran /hukumkoran/16/02/07/

KH Muhammad Amir SH: Kyai Ngruki Yang Penuh Inspirasi, http://www.kompasiana. com /hattasyamsuddin/_551fb659a33311fa29b6732d

Sejarah Perkembangan Pendidikan Al-Islam Surakarta, Stensilan, tahun 1978.

http://www.alkhoirot.com/beda-pondok-modern-dan-pesantren-salaf. dikutip tanggal 24 Mei 2016. 